\title{
Pembuatan Game Edukasi Tuntunan Sholat Fardhu Untuk Anak Berbasis Android
}

\author{
Celo Belia Putri Birastuti, Fatah Yasin Al Irsyadi \\ Fakultas Komunikasi dan Informatika \\ Universitas Muhammadiyah Surakarta \\ Surakarta, Indonesia \\ celobelia96@gmail.com, Fatah.Yasin@ums.ac.id
}

\begin{abstract}
Abstraksi - Sholat Fardhu merupakan tiang agama yang wajib dilaksanakan bagi umat Islam. Sholat Fardhu terdiri dari subuh, dzuhur, asar, maghrib, dan isya'. Sholat harus dikenalkan dan ditanamkan pada anak sejak dini. Namun pembelajaran sholat di sekolah umum nya masih menggunakan media cetak yang membuat anak menjadi cepat bosan dan materi yang disampaikan pun sulit di terima. Oleh karena itu perlu adanya media pembelajaran yang lebih interaktif dan menarik seperti media game edukatif sehingga anak tidak mudah bosan ketika mempelajari materi sholat fardhu. Seiring dengan perkembangan teknologi hampir setiap anak memiliki smartphone yang sering digunakan untuk bermain, maka game tuntunan sholat ini dikembangkan berbasis android sehingga mudah digunakan kapanpun dan dimanapun. Game dibangun menggunakan software Construct 2 dan menggunakan metode yang melalui beberapa tahapan yaitu analisis kebutuhan berupa observasi dan wawancara langsung, pengumpulan data, perancangan aplikasi, pembuatan aplikasi dan pengujian. Pembuatan game ini bertujuan untuk mempermudah dan meningkatkan minat anak dalam mempelajari setiap gerakan dan bacaan sholat fardhu. Hasil dari penelitian ini berupa game edukasi tuntunan sholat yang memiliki dua menu utama yaitu belajar dan bermain. Berdasarkan hasil pengujian yang dilakukan di SD MIM Gonilan dapat disimpulkan media pembelajaran game edukatif yang dibuat sangat menarik, interaktif, dan membantu siswa dalam mempelajari bacaan dan gerakan sholat fardhu dengan benar.
\end{abstract}

Katakunci - sholat fardhu; game edukasi; android; construct 2; corel draw $\mathrm{X} 7$

\section{PENDAhuluan}

Sholat adalah serangkaian kegiatan khusus yang dimulai dengan takbiratul ihram dan diakhiri dengan salam [1]. Sholat Fardhu merupakan salah satu ibadah wajib bagi umat Islam yang terdiri dari subuh, dzuhur, asar, maghrib, dan isya'. Umat muslim wajib melaksanakannya karena sholat merupakan tiang agama yang membedakan agama Islam dengan agama lainnya. Allah SWT telah memudahkan umatnya untuk melaksanakan sholat dalam kondisi apapun dan dalam segala usia.

Berdasarkan observasi yang telah dilakukan di SD Madrasah Ibtidaiyah Muhammadiyah (MIM) Gonilan
Kartasura, diketahui bahwa masalah yang dihadapi saat mengajarkan anak-anak tersebut materi Sholat adalah tidak adanya media pembelajaran yang interaktif. Media pembelajaran yang digunakan masih berupa buku dan tulisan di papan tulis. Namun pada anak mempelajari buku dirasa kurang menarik dan kurang interaktif karena anak akan mudah bosan dan sulit memahami materi yang di sampaikan. Akhirnya guru pun harus mengulangi materi yang justru membuat para siswa tidak fokus dan mengantuk saat di kelas.

\section{DASAR TEORI DAN TINJAUAN PUSTAKA}

Dalam perkembangan dunia yang begitu pesat, pembelajaran sholat harus dikenalkan dan ditanamkan pada diri anak mulai sejak dini agar anak terbiasa untuk menjalankan kewajibannya sebagai umat muslim. Pembelajaran sholat tidak hanya melalui buku pembelajaran tapi bisa melalui media pembelajaran seperti game edukatif. Game sangat mudah didapatkan dan dimainkan melalui komputer maupun melalui smartphone yang di era saat ini hampir setiap anak memilikinya. Pemanfaatan smartphone di dunia yang sangat berkembang saat ini mampu mendukung di beberapa bidang salah satunya sebagai media pembelajaran [6]. Selain itu teknologi seluler memiliki potensi yang besar untuk memfasilitasi metode pendidikan yang lebih inovatif [5]. Selain itu game edukatif merupakan alat yang efektif untuk mendidik anak dengan cara yang interaktif karena menggabungkan antara pendidikan di dalam permainan sehingga mampu menciptakan jalur belajar yang efisien.

Para ahli menyatakan bahwa melalui permainan mampu meningkatkan intelektual anak dan mengembangkan motivasi anak untuk belajar. Belajar melalui game edukatif dapat memberi dampak efektif dalam peningkatan perkembangan kemampuan kognitif siswa [2]. Dalam Pendidikan anak usia dini, permainan menjadi cara belajar yang paling efektif dalam membantu perkembangan anak karena dengan bermain anak belajar mengenal lingkungan sekitar serta mampu mengembangkan mental, fisik, sosial, dan emosionalnya [4]. Permainan memang sudah tak asing di kalangan anak hingga orang dewasa, terlebih di kalangan anak pada usia dini. Pada usia dini anak akan belajar melalui apa yang mereka lihat di 
lingkungan sekitarnya dan anak akan mudah mengingat serta mampu menerapkannya didalam kehidupan sehari-hari. Permainan menjadi daya tarik tersendiri bagi anak karena melalui permainan anak akan belajar mengenal dan berkomunikasi dengan objek baru, melatih anak untuk bersikap jujur dalam berinteraksi dengan temannya, serta mampu meningkatkan dan mengasah kreativitas anak. Game edukasi dapat merangsang daya pikir anak sehingga dapat meningkatkan kemampuan anak dalam berkonsentrasi dan memecahkan masalah [4].

Dengan adanya permasalahan yang ada maka perlu pengembangan media pembelajaran yaitu melalui game edukatif dengan memanfaatkan smartphone melalui sistem android yang mudah digunakan. Oleh karena itu pada Tugas Akhir ini dibuatlah Game Edukasi Pengenalan Tuntunan Sholat Fardhu Untuk Anak Berbasis Android menggunakan Construct 2 dengan menerapkan sistem belajar sambil bermain. Di dalam game ini anak dapat belajar sholat fardhu beserta bacaan-bacaan dalam sholat dengan gerakannya yang lebih interaktif yang diharapkan dapat mempermudah proses belajar pada anak. Selain itu anak-anak juga dapat bermain seperti tebak gerakan sholat, pasangkan gerakan, dan puzzle yang diharapkan anak menjadi tidak gampang bosan dan materi yang ada di dalam permainan bisa lebih mudah ditangkap oleh anak.

\section{METODE}

Dalam pengembangan game tuntunan sholat fardhu untuk anak pada penelitian ini dimulai dengan melakukan observasi langsung untuk mengetahui masalah yang ada dalam proses pembelajaran di kelas serta mengidentifikasi penyelesaian yang dapat digunakan untuk mengatasi masalah tersebut. Penulis melakukan wawancara terhadap kepala sekolah SD Madrasah Ibtidaiyah Muhammadiyah (MIM) Gonilan untuk mendapatkan data dan dikumpulkan sehingga aplikasi yang dibangun nantinya akan berjalan sesuai dengan kebutuhan oleh pengguna. Hasil wawancara adalah sebagai berikut:

- Sholat fardhu sudah dikenalkan kepada siswa mulai sejak kelas $1 \mathrm{SD}$

- Tidak adanya media pembelajaran interaktif yang dapat digunakan untuk membantu mempermudah para siswa dalam mempelajari materi tentang shalat

- Materi tentang sholat disampaikan melalui buku dan tulisan di papan tulis yang disampaikan oleh guru, sehingga membuat anak cepat bosan dan susah fokus.

- Kurikulum SD MIM Gonilan sesuai dengan KTSP yang berlaku, sehingga materi tentang sholat hanya terdapat di mata pelajaran tertentu

\section{A. Perancangan Sistem}

\section{1) Gambaran Umum Aplikasi}

Gambaran umum dari game edukasi tuntunan sholat fardhu yang dibuat adalah sebagai berikut:

- Game edukasi ini berisi materi tentang sholat untuk anak.

- Construct 2 merupakan software utama yang digunakan untuk membangun game ini serta menggunakan software Corel Draw $x 7$ untuk membantu dalam pembuatan aset-aset objek animasi yang akan digunakan dalam game.

- Tampilan pertama game edukasi tuntunan shalat fardhu ini terdapat 2 menu utama, yaitu menu belajar yang berisi materi tentang tata cara sholat, dan menu bermain yang terdapat beberapa pilihan game yang dapat dimainkan.

- Pada menu permainan terdapat tata cara bermain dan di akhir permainan akan muncul halaman hasil akhir yang menampilkan skor penilaian serta bintang yang di dapat pemain, dan highscore atau nilai tertinggi yang pernah diperoleh pemain game tersebut.

\section{2) Storyboard}

Proses selanjutnya dalam penelitian ini adalah pembuatan rancangan awal desain aplikasi melalui storyboard, berupa serangkaian sketsa yang digunakan sebagai panduan pembuatan aplikasi game edukasi tuntunan shalat fardhu sesuai dengan kebutuhan agar memudahkan membaca alur kerja aplikasi. Storyboard dari game edukasi ditunjukkan pada gambar dibawah ini:

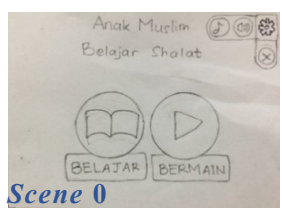

Gambar 1. Storyboard Menu Awal Game
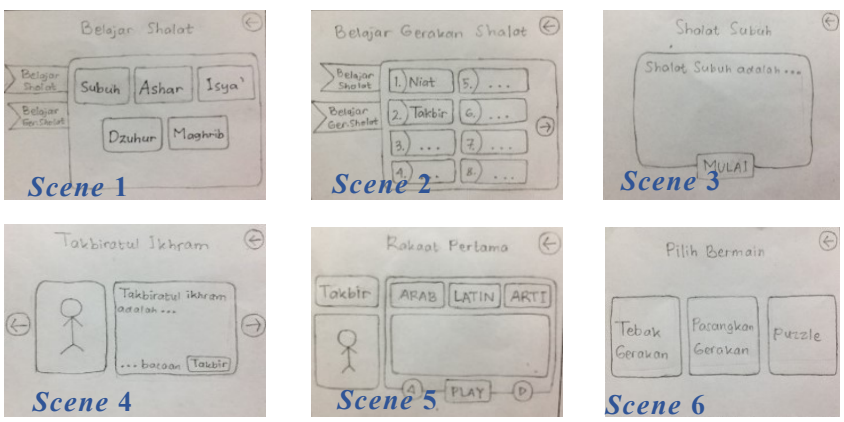

Scene 4
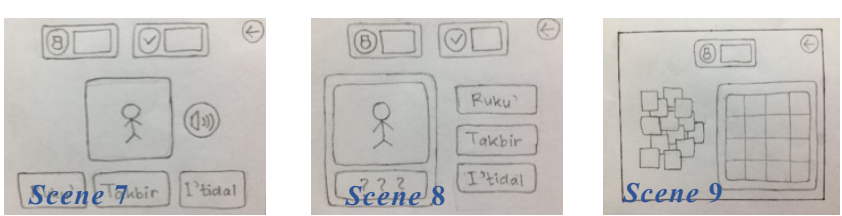

Gambar 2. Storyboard game tuntunan sholat fardhu 
TABEL 1. PENJELASAN STORYBOARD

\begin{tabular}{ll}
\hline \hline \multicolumn{1}{c}{ Komponen } & \multicolumn{1}{c}{ Deskripsi } \\
\hline Tema Game & Game Edukasi Tuntunan Sholat Fardhu \\
Bahasa & Indonesia \\
Sistem & Game ini terdiri dari 10 scene, yaitu scene 0 sampai scene 9 \\
Permainan & Scene 0 menu utama game, terdapat pilihan menu 'belajar' \\
& atau 'bermain' \\
& Scene 1 halaman menu pilihan 'belajar sholat fardhu' \\
& Scene 2 halaman menu pilihan 'belajar gerakan sholat' \\
& Scene 3 sampai 5 tampilan pengenalan shalat fardhu dan \\
& gerakan sholat \\
& Scene 6 halaman menu pilihan bermain \\
& Scene 7 tampilan permainan 'tebak gerakan' \\
& Scene 8 tampilan permainan 'pasangkan gerakan' \\
& Scene 9 tampilan permainan 'puzzle' \\
\hline \hline
\end{tabular}

\section{B. Pembangunan Aplikasi}

Aplikasi game dibagun menggunakan software utama Construct 2. Software pendukung lainnya yaitu Corel Draw $x 7$ untuk membuat dan mengedit desain aset-aset objek animasi yang terdapat dalam game. Selain itu audio suara yang digunakan bersumber dari suara penulis yang di edit menggunakan aplikasi Voice Changer and Sound Effect dan audio pendukung lainnya seperti sound effect juga diambil dari internet serta menggunakan Phonegap untuk build ke android.

\section{Pengujian Aplikasi}

Pengujian aplikasi game edukasi ini dilakukan di SD MIM Gonilan dengan melibatkan siswa kelas 1 SD dan di damping oleh guru pengajar. Serta pengujian dilakukan dengan meminta guru-guru pengajar dan beberapa siswa untuk mengisi kuesioner yang telah disediakan oleh penulis untuk menganalisa kemampuan dari aplikasi yang telah di uji coba.

\section{HASIL DAN PEMBAHASAN}

\section{A. Hasil Aplikasi}

\section{1) Tampilan Menu Utama}

Gambar 3 merupakan tampilan awal saat aplikasi pertama kali dijalankan, menampilkan 2 menu utama yaitu Menu Belajar dan Menu Bermain.

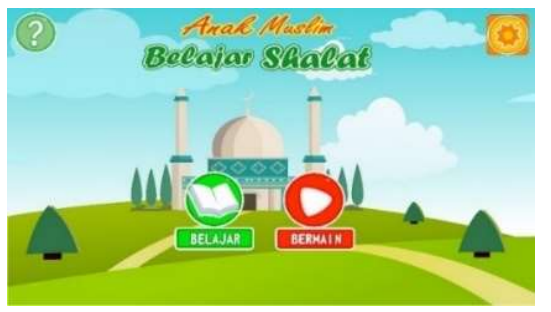

Gambar 3. Tampilan menu awal

Selain itu terdapat beberapa tombol seperti tombol petunjuk permainan, tombol pengaturan yang jika di klik akan menampilkan tombol musik, tombol suara, dan tombol keluar.

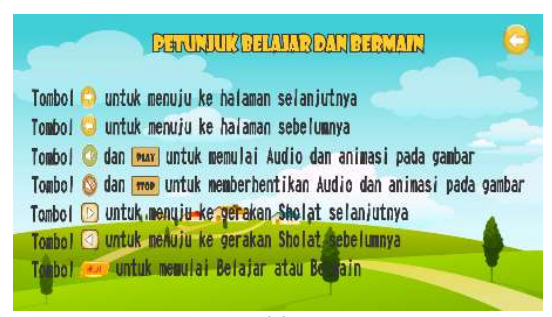

(a)

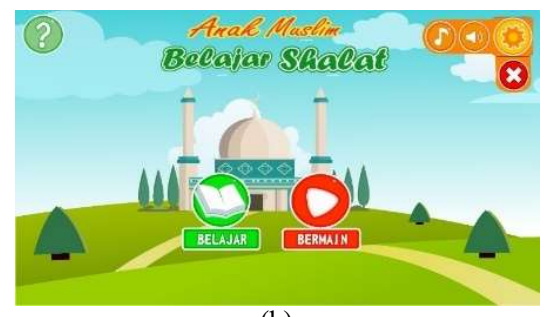

(b)

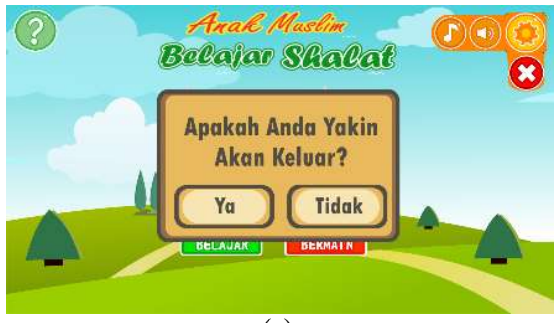

(c)

Gambar 4. Petunjuk Permainan (a), Menu Pengaturan (b), Menu Keluar (c)

a) Petunjuk Permainan (Gambar 4a) : hasil dari tombol tanda tanya di sisi kiri atas pada halaman awal berisi fungsi tombol-tombol dalam permainan.

b) Pengaturan (Gambar 4b) : terdapat sub menu dari menu pengaturan yaitu tombol musik serta tombol suara yang digunakan untuk mengaktifkan dan memberhentikan musik atau suara yang ada di dalam permainan, serta terdapat menu keluar (Gambar 4c) untuk keluar dari permainan

\section{2) Tampilan Menu Belajar}

Pada Menu Belajar terdapat 2 sub menu yaitu Menu Belajar Sholat dan Belajar Gerakan Sholat.

\section{a) Tampilan Menu Belajar Sholat}

Menu Belajar Sholat akan menampilkan 5 jenis Sholat Fardhu yaitu Subuh, Dzuhur, Ashar, Maghrib, dan Isya seperti pada Gambar 5. Pada setiap pilihan Sholat Fardhu terdapat penjelasan cara dan waktu pelaksanaannya. Halaman selanjutnya setelah pengguna memilih salah satu jenis Sholat Fardhu terdapat langkah-langkah tata cara sholat yang dilengkapi dengan bacaan sholat dan animasi gerakan shalat (Gambar 6). Tombol Play digunakan untuk memulai animasi gerakan sholat pada gambar yang di ikuti dengan suara bacaan Sholat. 


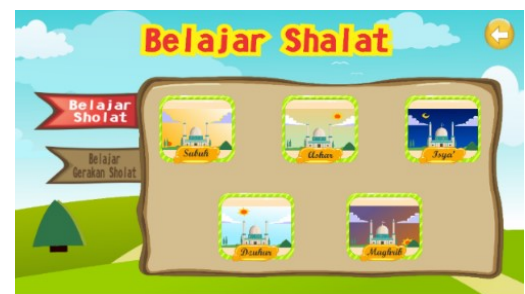

Gambar 5. Tampilan Menu Belajar Sholat

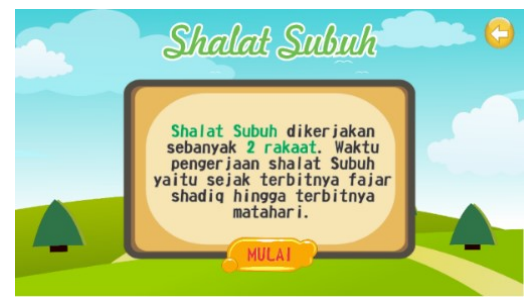

(a)

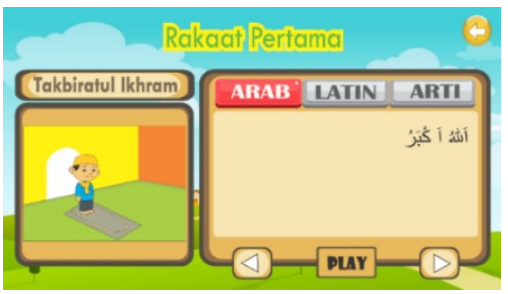

(b)

Gambar 6. Penjelasan Sholat Fardhu (a), Bacaan dan Gerakan Sholat Fardhu (b)

\section{b) Tampilan Menu Belajar Gerakan Sholat}

Selain belajar Sholat Fardhu pada permainan ini terdapat Menu Belajar Gerakan Sholat. Pada menu ini pengguna dapat langsung belajar gerakan sholat sesuai dengan apa yang ingin dipelajari. Halaman ini menampilkan semua daftar pilihan gerakan sholat seperti pada Gambar 7. Setelah pengguna memilih salah satu gerakan sholat maka akan muncul gambar gerakan sholat beserta penjelasannya. Setiap penjelasan terdapat tulisan berwarna (Gambar 8a) apabila tulisan berwarna tersebut di klik maka akan muncul halaman yang berisi bacaan shalat dan animasi gerakan sholat, selain itu terdapat tombol Play untuk memulai animasi gerakan. Kemudian jika pengguna ingin ke gerakan sholat selanjutnya maka tekan tombol Next yang ada di sisi kanan, dan untuk mengulang gerakan sebelum nya maka tekan tombol Back yang ada di sisi kiri.

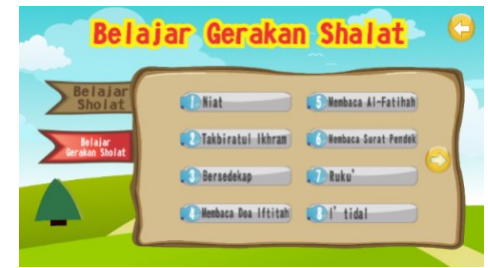

Gambar 7. Tampilan Belajar Gerakan Sholat

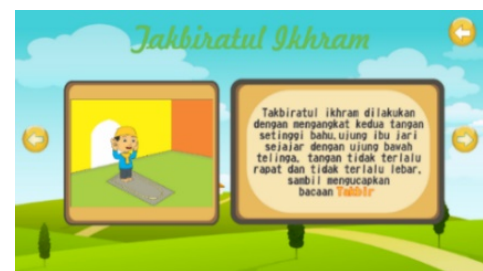

(a)

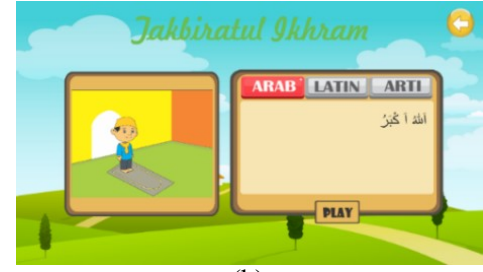

(b)

Gambar 8. Penjelasan Gerakan Sholat (a), Bacaan dan Gerakan Sholat (b)

\section{3) Tampilan Menu Bermain}

Pada Gambar 9 merupakan tampilan dari Menu Bermain, di menu ini terdapat 3 pilihan permainan yang dapat dimainkan yaitu Tebak Gerakan, Pasangkan Gerakan, dan Puzzle.

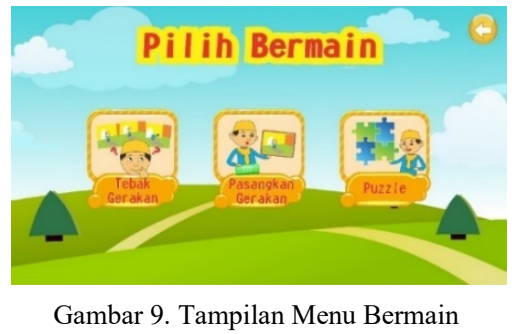

\section{a) Tampilan Permainan Tebak Gerakan}

Gambar 10 merupakan tampilan permainan tebak gerakan. Pada permainan ini akan muncul soal berupa gambar beserta tiga pilihan jawaban. Pemain akan diminta untuk memilih salah satu jawaban nama gerakan shalat yang sesuai dengan soal. Tombol suara di samping gambar digunakan untuk mendengarkan bacaan sholat dan memulai animasi. Terdapat kolom nilai dimana jika jawaban benar maka score bertambah 10 poin serta akan menampilkan emoticon senang, dan ketika jawaban salah maka score berkurang 5 poin serta akan muncul emotion sedih. Selain itu terdapat kolom waktu bermain yang akan di hitung secara mundur, jika waktu telah menunjukkan angka 0 atau jika semua soal telah terjawab maka permainan akan selesai. Pada halaman hasil akhir menampilkan score hasil bermain, bintang, dan highscore. Semakin banyak soal yang dapat terjawab benar maka semakin banyak pula score dan bonus bintang yang akan didapatkan. 


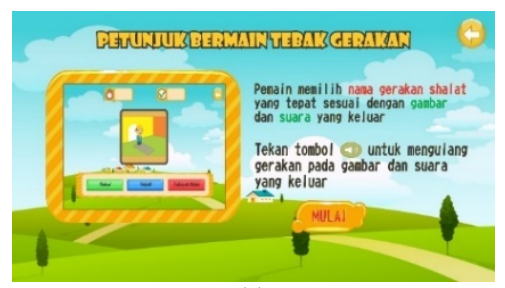

(a)

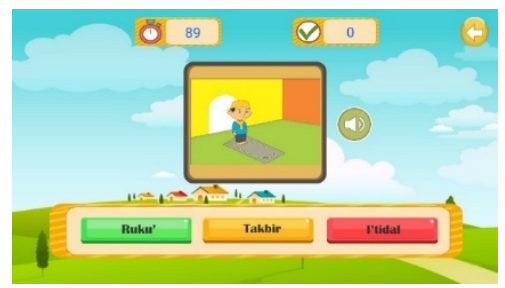

(b)

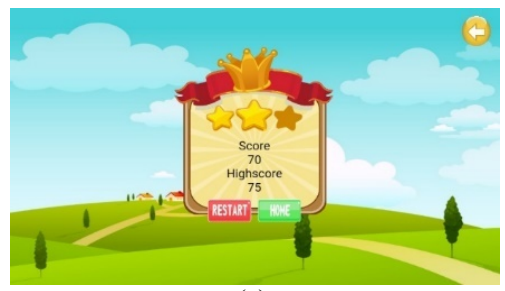

(c)

Gambar 10. Awal Permainan Tebak Gerakan (a), Tampilan Bermain Tebak Gerakan (b), Hasil Akhir Permainan Tebak Gerakan (c)

\section{b) Tampilan Permainan Pasangkan Gerakan}

Gambar 11 merupakan tampilan permainan pasangkan gerakan, dimana terdapat satu soal gambar gerakan sholat dan 3 pilihan jawaban. Pemain diminta untuk memilih salah satu jawaban yang sesuai dengan gerakan pada soal dengan cara menggeserkan salah satu jawaban yang ada di sisi kanan ke kolom yang tersedia pada Panel yang berada di bawah gambar. Seperti di permainan sebelumnya yaitu Tebak Gerakan, di permainan ini juga terdapat kolom score, kolom waktu bermain, serta di akhir akan muncul tampilan berisi score, bintang dan highscore atau nilai tertinggi.

\section{c) Tampilan Permainan Puzzle}

Gambar 12 merupakan tampilan dari permainan puzzle. Pada permainan ini pemain diminta menyusun potonganpotongan gambar menjadi gambar yang utuh, dengan menarik potongan gambar dan meletakkannya ke kotak yang sudah disediakan. Berbeda dengan permainan Tebak Gambar dan Pasangkan Gerakan di permainan puzzle ini hanya ada kolom waktu yang berjalan hinga detik ke 120, jika pemain belum bisa menyelesaikan puzzle pada detik ke 120 maka permainan akan selesai dan akan tampil halaman hasil akhir yang terdapat bintang, waktu yang digunakan dalam menyusun puzzle, dan score. Semakin cepat pemain menyelesaikan susunan puzzle maka semakin tinggi score dan bintang yang didapat.

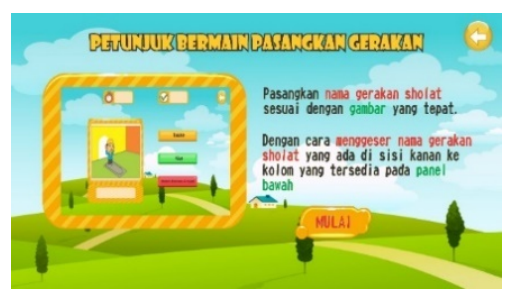

(a)

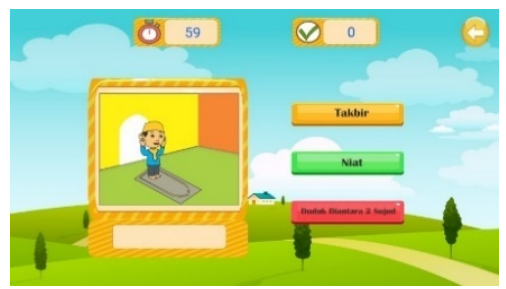

(b)

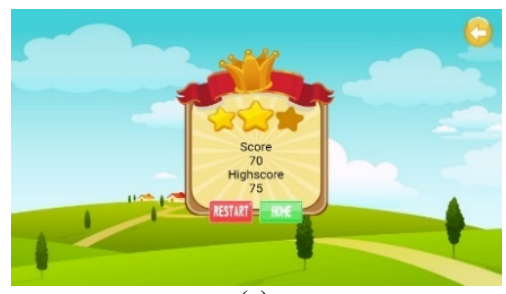

(c)

Gambar 11. Awal Permainan Pasangkan Gerakan (a), Tampilan Bermain Pasangkan Gerakan (b), Hasil Akhir Permainan Pasangkan Gerakan (c)

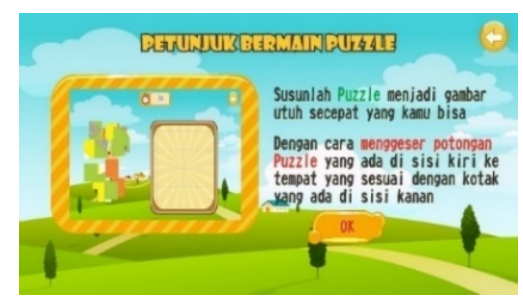

(a)

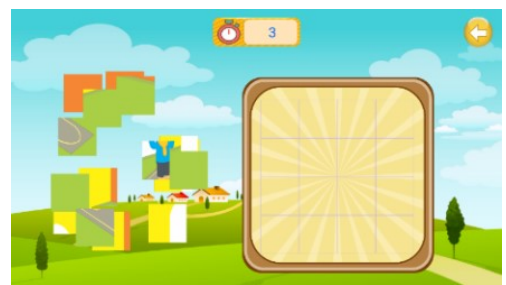

(b)

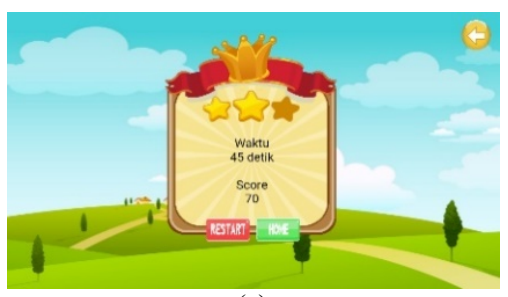

(c)

Gambar 12. Awal Permainan Puzzle (a), Tampilan Bermain Puzzle (b), Hasil Akhir Permainan Puzzle (c) 


\section{B. Hasil Pengujian}

Pengujian game edukasi tuntunan sholat ini dilakukan dengan 2 cara yaitu Pengujian Black Box dan Pengujian Penerimaan User

\section{1) Pengujian Black Box}

Pengujian Black Box bertujuan untuk mengetahui spesifikasi fungsional dari perangkat lunak yang dibangun dengan megecek apakah hasil output sudah sesuai yang diharapkan. Pengujian ini dilakukan pada Laptop HP dengan windows 10, Laptop Asus dengan windows 10, Smartphone Samsung dengan OS Nougat, Smartphone Oppo dengan OS Lollipop, dan Smartphone Vivo dengan OS Marshmalllow. Hasil pengujian Black Box game edukasi tuntunan sholat fardhu dapat berjalan dengan baik

TABEL 2. Hasil PENGUJian BLACK BOX

\begin{tabular}{|c|c|c|c|c|}
\hline Yang diuji & Pengujian & Input & Output & $\begin{array}{c}\text { Hasi } \\
1\end{array}$ \\
\hline \multirow[b]{3}{*}{ Menu Utama } & Ikon belajar & $\begin{array}{l}\text { Klik ikon } \\
\text { belajar }\end{array}$ & $\begin{array}{c}\text { Menuju ke halaman } \\
\text { belajar }\end{array}$ & Valid \\
\hline & $\begin{array}{c}\text { Ikon } \\
\text { bermain }\end{array}$ & $\begin{array}{c}\text { Klik ikon } \\
\text { bermain }\end{array}$ & $\begin{array}{c}\text { Menuju ke halaman } \\
\text { bermain }\end{array}$ & Valid \\
\hline & \begin{tabular}{|c|} 
Semua \\
tombol di \\
Menu Utama
\end{tabular} & $\begin{array}{c}\text { Klik } \\
\text { masing- } \\
\text { masing } \\
\text { tombol }\end{array}$ & $\begin{array}{c}\text { Setiap pilihan tombol } \\
\text { yang di klik akan berjalan } \\
\text { sesuai dengan fungsinya }\end{array}$ & Valid \\
\hline \multirow{3}{*}{$\begin{array}{l}\text { Menu } \\
\text { Belajar }\end{array}$} & $\begin{array}{l}\text { Dua daftar } \\
\text { pilihan } \\
\text { belajar }\end{array}$ & $\begin{array}{l}\text { Klik } \\
\text { pilihan } \\
\text { belajar }\end{array}$ & $\begin{array}{c}\text { Setiap pilihan belajar } \\
\text { yang di klik akan menuju } \\
\text { ke halaman belajar yang } \\
\text { dipilih }\end{array}$ & Valid \\
\hline & $\begin{array}{c}\text { Semua } \\
\text { tombol di } \\
\text { Menu } \\
\text { Belajar } \\
\end{array}$ & $\begin{array}{l}\text { Klik } \\
\text { masing- } \\
\text { masing } \\
\text { tombol }\end{array}$ & $\begin{array}{c}\text { Setiap pilihan tombol } \\
\text { yang di klik akan berjalan } \\
\text { sesuai dengan fungsinya }\end{array}$ & Valid \\
\hline & \begin{tabular}{|c|} 
Animasi \\
pada \\
gerakan dan \\
bacaan \\
sholat \\
\end{tabular} & $\begin{array}{l}\text { Klik } \\
\text { tombol } \\
\text { Play }\end{array}$ & $\begin{array}{l}\text { Animasi akan bergerak } \\
\text { sesuai dengan bacaan } \\
\text { sholat yang keluar }\end{array}$ & Valid \\
\hline $\begin{array}{l}\text { Menu } \\
\text { Belajar } \\
\text { Sholat }\end{array}$ & $\begin{array}{l}\text { Lima daftar } \\
\text { pilihan } \\
\text { belajar } \\
\text { sholat }\end{array}$ & $\begin{array}{l}\text { Klik } \\
\text { pilihan } \\
\text { sholat }\end{array}$ & $\begin{array}{c}\text { Setiap pilihan sholat yang } \\
\text { di klik akan menuju ke } \\
\text { halaman sholat yang } \\
\text { dipilih }\end{array}$ & Valid \\
\hline $\begin{array}{l}\text { Menu } \\
\text { Belajar } \\
\text { Gerakan } \\
\text { Sholat }\end{array}$ & $\begin{array}{c}\text { Tiga belas } \\
\text { daftar } \\
\text { pilihan } \\
\text { belajar } \\
\text { gerakan } \\
\text { sholat }\end{array}$ & $\begin{array}{l}\text { Klik } \\
\text { pilihan } \\
\text { gerakan } \\
\text { sholat }\end{array}$ & $\begin{array}{l}\text { Setiap pilihan gerakan } \\
\text { sholat yang di klik akan } \\
\text { menuju ke halaman } \\
\text { gerakan sholat yang } \\
\text { dipilih }\end{array}$ & Valid \\
\hline \multirow{3}{*}{$\begin{array}{c}\text { Menu } \\
\text { Bermain }\end{array}$} & $\begin{array}{l}\text { Tiga daftar } \\
\text { pilihan } \\
\text { permainan }\end{array}$ & $\begin{array}{c}\text { Klik } \\
\text { masing- } \\
\text { masing } \\
\text { pilihan } \\
\text { permainan } \\
\end{array}$ & $\begin{array}{c}\text { Setiap pilihan permainan } \\
\text { yang di klik akan menuju } \\
\text { ke halaman bermain yang } \\
\text { dipilih }\end{array}$ & Valid \\
\hline & $\begin{array}{l}\text { Semua } \\
\text { tombol di } \\
\text { Menu } \\
\text { Bermain }\end{array}$ & $\begin{array}{l}\text { Klik } \\
\text { masing- } \\
\text { masing } \\
\text { tombol }\end{array}$ & $\begin{array}{l}\text { Setiap tombol yang di } \\
\text { klik akan berjalan sesuai } \\
\text { dengan fungsinya }\end{array}$ & Valid \\
\hline & Scoring & $\begin{array}{l}\text { Lakukan } \\
\text { debug }\end{array}$ & $\begin{array}{l}\text { Scoring dapat betambah } \\
\text { jika benar, dapat }\end{array}$ & Valid \\
\hline
\end{tabular}

\begin{tabular}{|c|c|c|c|c|}
\hline Yang diuji & Pengujian & Input & Output & $\underset{\text { Hasi }}{\text { Ha }}$ \\
\hline & & permainan & $\begin{array}{c}\text { berkurang jika salah, dan } \\
\text { akan ditampilkan pada } \\
\text { halaman bermain }\end{array}$ & \\
\hline & Timer & $\begin{array}{l}\text { Lakukan } \\
\text { permainan }\end{array}$ & $\begin{array}{c}\text { Timer dapat menampilkan } \\
\text { waktu permainan, jika } \\
\text { waktu habis maka game } \\
\text { akan berakhir }\end{array}$ & Valid \\
\hline \multirow[t]{2}{*}{$\begin{array}{l}\text { Permainan } \\
\text { Tebak } \\
\text { Gerakan }\end{array}$} & $\begin{array}{l}\text { Pemilihan } \\
\text { jawaban } \\
\text { yang sesuai }\end{array}$ & $\begin{array}{l}\text { Klik } \\
\text { tombol } \\
\text { pilihan } \\
\text { jawaban }\end{array}$ & $\begin{array}{c}\text { apabila jawaban benar } \\
\text { maka score akan } \\
\text { bertambah dan jika } \\
\text { jawaban salah maka score } \\
\text { akan berkuran }\end{array}$ & Valid \\
\hline & $\begin{array}{l}\text { Tombol } \\
\text { musik }\end{array}$ & $\begin{array}{c}\text { Klik } \\
\text { tombol } \\
\text { musik }\end{array}$ & $\begin{array}{c}\text { Animasi akan bergerak } \\
\text { sesuai dengan suara yang } \\
\text { keluar }\end{array}$ & Valid \\
\hline $\begin{array}{c}\text { Permainan } \\
\text { Pasangkan } \\
\text { Gerakan }\end{array}$ & $\begin{array}{l}\text { Pemilihan } \\
\text { nama } \\
\text { gerakan }\end{array}$ & $\begin{array}{l}\text { Drag and } \\
\text { drop nama } \\
\text { gerakan }\end{array}$ & $\begin{array}{c}\text { Pilihan nama gerakan } \\
\text { benar maka akan } \\
\text { menempel ke kotak } \\
\text { jawaban yang tersedia }\end{array}$ & Valid \\
\hline $\begin{array}{l}\text { Permainan } \\
\text { Puzzle }\end{array}$ & $\begin{array}{c}\text { Pemilihan } \\
\text { potongan } \\
\text { gambar }\end{array}$ & $\begin{array}{l}\text { Drag and } \\
\text { drop } \\
\text { potongan } \\
\text { gambar }\end{array}$ & $\begin{array}{c}\text { Apabila meletakkan } \\
\text { potongan gambar benar } \\
\text { maka akan menempel ke } \\
\text { kotak gambar dan jika } \\
\text { salah akan otomatis } \\
\text { kembali }\end{array}$ & Valid \\
\hline
\end{tabular}

\section{2) Pengujian Penerimaan User}

Pengujian dilakukan dengan pengenalan mengenai menumenu dan tata cara bermain di dalam game tuntunan sholat kemudian dilanjutkan dengan praktek penggunaan game secara langsung. Pengujiaan dilakukan di SD MIM Gonilan, Kartasura, pada hari Senin, 30 April 2018 yang melibatkan 46 siswa siswi dengan 15 guru pendamping. Penulis meminta guru untuk mengisi kuisioner yang diberikan oleh penulis untuk memberikan penilaian terhadap hasil game edukasi tuntunan sholat fardhu, dengan jumlah responden 15 guru pendamping. Berikut adalah hasil kuisioner.

TABEL 3. HASIL KUISIONER

\begin{tabular}{|c|l|c|c|c|c|c|}
\hline No & \multicolumn{1}{|c|}{ Pertanyaan } & SS & S & N & TS & $\begin{array}{c}\text { ST } \\
\text { S }\end{array}$ \\
\hline 1 & $\begin{array}{l}\text { Apakah tampilan game cukup } \\
\text { menarik? }\end{array}$ & $\begin{array}{c}87 \\
\%\end{array}$ & $\begin{array}{c}13 \\
\%\end{array}$ & $\begin{array}{c}0 \\
\%\end{array}$ & $\begin{array}{c}0 \\
\%\end{array}$ & $\begin{array}{c}0 \\
\%\end{array}$ \\
\hline 2 & $\begin{array}{l}\text { Apakah game bersifat interaktif } \\
\text { terhadap } \\
\text { penggunanya? }\end{array}$ & $\begin{array}{c}60 \\
\%\end{array}$ & $\begin{array}{c}40 \\
\%\end{array}$ & $\begin{array}{c}0 \\
\%\end{array}$ & $\begin{array}{c}0 \\
\%\end{array}$ & $\begin{array}{c}0 \\
\%\end{array}$ \\
\hline 3 & $\begin{array}{l}\text { Apakah game mudah dimainkan? } \\
4\end{array}$ & $\begin{array}{l}67 \\
\%\end{array}$ & $\begin{array}{c}33 \\
\%\end{array}$ & $\begin{array}{c}0 \\
\%\end{array}$ & $\begin{array}{c}0 \\
\%\end{array}$ & $\begin{array}{c}0 \\
\%\end{array}$ \\
\hline 5 & $\begin{array}{l}\text { Apakah para siswa tampak } \\
\text { antusias saat bermain game ini? } \\
\text { dalam game ini sesuai dengan } \\
\text { kurikulum sekolah? }\end{array}$ & $\begin{array}{c}60 \\
\%\end{array}$ & $\begin{array}{c}40 \\
\%\end{array}$ & $\begin{array}{c}0 \\
\%\end{array}$ & $\begin{array}{c}0 \\
\%\end{array}$ & $\begin{array}{c}0 \\
\%\end{array}$ \\
\hline 6 & $\begin{array}{l}\text { Apakah gambar pada Menu } \\
\text { Belajar sesuai dengan gerakan } \\
\text { sholat sehari-hari? }\end{array}$ & $\begin{array}{c}87 \\
\%\end{array}$ & $\begin{array}{c}0 \\
\%\end{array}$ & $\begin{array}{c}0 \\
\%\end{array}$ & $\begin{array}{c}0 \\
\%\end{array}$ \\
\hline 7 & $\begin{array}{l}\text { Apakah game ini memudahkan } \\
\text { anak untuk belajar tata cara shalat } \\
\text { beserta bacaannya? }\end{array}$ & $\begin{array}{c}93 \\
\%\end{array}$ & $\begin{array}{c}7 \\
\%\end{array}$ & $\begin{array}{c}0 \\
\%\end{array}$ & $\begin{array}{c}0 \\
\%\end{array}$ & $\begin{array}{c}0 \\
\%\end{array}$ \\
\hline
\end{tabular}




\begin{tabular}{|c|l|c|c|c|c|c|}
\hline No & \multicolumn{1}{|c|}{ Pertanyaan } & SS & S & N & TS & $\begin{array}{c}\text { ST } \\
\text { S }\end{array}$ \\
\hline 8 & $\begin{array}{l}\text { Apakah game ini membantu guru } \\
\text { dalam memvariasikan metode } \\
\text { belajar siswa? }\end{array}$ & $\begin{array}{c}80 \\
\%\end{array}$ & $\begin{array}{c}20 \\
\%\end{array}$ & $\begin{array}{c}0 \\
\%\end{array}$ & $\begin{array}{c}0 \\
\%\end{array}$ & $\begin{array}{c}0 \\
\%\end{array}$ \\
\hline 9 & $\begin{array}{l}\text { Apakah game ini dapat menjadi } \\
\text { sarana belajar mengajar dan } \\
\text { bermain? }\end{array}$ & $\begin{array}{c}73 \\
\%\end{array}$ & $\begin{array}{c}20 \\
\%\end{array}$ & $\begin{array}{c}7 \\
\%\end{array}$ & $\begin{array}{c}0 \\
\%\end{array}$ & $\begin{array}{c}0 \\
\%\end{array}$ \\
\hline 10 & $\begin{array}{l}\text { Apakah android sebagai media } \\
\text { penggunaannya cukup mudah } \\
\text { digunakan? }\end{array}$ & $\begin{array}{c}60 \\
\%\end{array}$ & $\begin{array}{c}40 \\
\%\end{array}$ & $\begin{array}{c}0 \\
\%\end{array}$ & $\begin{array}{c}0 \\
\%\end{array}$ & $\begin{array}{c}0 \\
\%\end{array}$ \\
\hline
\end{tabular}

Berikut adalah hasil analisa yang diperoleh dari kuisioner yang telah diisi oleh 15 responden:

- Pada pertanyaan nomor 1, menyebutkan bahwa $87 \%$ responden menyatakan sangat setuju (SS) dan 13\% responden menyatakan setuju (S). Artinya, game edukasi tuntunan sholat fardhu ini memiliki tampilan yang cukup menarik.

- Pada pertanyaan nomor 2, meyebutkan bahwa $60 \%$ responden menyatakan sangat setuju (SS) dan $40 \%$ responden menyatakan setuju (S). Artinya, game edukasi tuntunan sholat fardhu ini bersifat interaktif terhadap penggunanya.

- Pada pertanyaan nomor 3, menyebutkan bahwa $67 \%$ responden menyatakan sangat setuju (SS) dan 33\% responden menyatakan setuju (S). Artinya, game edukasi tuntunan sholat fardhu ini mudah dimainkan.

- Pada pertanyaan nomor 4, menyebutkan bahwa $60 \%$ responden menyatakan sangat setuju (SS) dan 40\% responden menyatakan setuju (S). Artinya, para siswa tampak sangat antusias dalam memainkan game tuntunan sholat fardhu ini baik belajar maupun bermain.

- Pada pertanyaan nomor 5, menyebutkan bahwa 53\% responden menyatakan sangat setuju (SS) dan 47\% responden menyatakan setuju (S). Artinya, materi yang ada di dalam game edukasi tuntunan sholat fardhu ini sudah sesuai dengan kurikulum yang digunakan di SD MIM Gonilan.

- Pada pertanyaan nomor 6, menyebutkan bahwa $87 \%$ responden menyatakan sangat setuju (SS) dan 13\% responden menyatakan setuju (S). Artinya, gambar animasi beserta bacaan sholat yang ada di game edukasi tuntunan sholat ini sudah sesuai dengan gerakan sholat sehari-hari.

- Pada pertanyaan nomor 7, menyebutkan bahwa $93 \%$ responden menyatakan sangat setuju (SS) dan 7\% responden menyatakan setuju (S).Artinya, game edukasi tuntunan sholat fardhu dapat memudahkan anak untuk belajar tata cara sholat dan bacaanya.

- Pada pertanyaan nomor 8, menyebutkan bahwa $80 \%$ responden menyatakan sangat setuju (SS) dan 20\% responden menyatakan setuju (S). Artinya, game edukasi tuntunan sholat fardhu ini dapat membantu para guru dalam memvariasikan metode pembelajaran.

- Pada pertanyaan nomor 9, menyebutkan bahwa $73 \%$ responden menyatakan sangat setuju (S) dan 20\% responden menyatakan setuju (S) serta $7 \%$ responden lainnya menyatakan netral $(\mathrm{N})$. Artinya, dengan game edukasi tuntunan sholat fardhu ini bisa digunakan sebagai sarana bermain sambil belajar pada siswa.

- Pada pertanyaan nomor 10, menyebutkan bahwa $60 \%$ responden menyatakan sangat setuju (SS) dan 40\% responden menyatakan setuju (S). Artinya, game edukasi tuntunan sholat fardhu dengan android sebagai media penggunaanya sangat mudah digunakan oleh para siswa.

\section{KESIMPULAN}

Berdasarkan hasil dari penelitian yang dilakukan dapat disimpulkan bahwa:

1. Game edukasi tuntunan sholat fardhu dibuat dengan tampilan menarik dan interaktif sehingga para siswa sangat antusias dalam memainkan game ini. Hal ini dibuktikan melalui hasil kuisioner yang diisi oleh 15 guru dengan jawaban $100 \%$ responden menyatakan setuju bahwa tampilan game cukup menarik dan bersifat interaktif.

2. Game edukasi tuntunan sholat fardhu dengan android sebagai media penggunaanya sangat mudah digunakan ketika memainkan game ini secara mandiri sehingga anak dapat tetap belajar kapanpun dan dimanapun. Hal ini dibuktikan dengan hasil kuisioner yang diisi oleh 15 guru dimana seluruh responden menyatakan setuju bahwa android sebagai media penggunaanya sangat mudah digunakan.

3. Game edukasi tuntunan sholat fardhu yang dibuat dapat membantu guru dalam memvariasikan metode belajar yang membuat anak menjadi lebih mudah memahami dan mempelajari materi tentang sholat sesuai dengan materi yang diberikan oleh guru. Hal ini dibuktikan melalui hasil kuisioner yang diisi oleh 15 guru dengan jawaban 100\% menyatakan setuju bahwa game tuntunan sholat mampu membantu anak untuk belajar tata cara sholat beserta bacaan dan gerakannya sehingga para siswa dapat mengikuti gerakan sholat dengan benar.

\section{DAFTAR PUSTAKA}

[1] Ardiansyah, R., \& Rahayu, S. (2016). Pengembangan Aplikasi Tata Cara Wudhu dan Shalat Untuk Anak Menggunakan Sistem Multimedia. Jurnal Algoritma, vol. 13(1), 2302-7339.

[2] Hermawan, D. P., Herumurti, D., \& Kuswardayan, I. (2017). Efektivitas Penggunaan Game Edukasi Berjenis Puzzle, RPG, dan Puzzle RPG Sebagai Sarana Belajar Matematika. Jurnal Ilmiah Teknologi Informasi, vol. 15(2), 195-205.

[3] Kumala, W. S. J. (2015). Pembuatan Media Pembelajaran Interaktif Pengenalan Benda Berbasis Game Untuk Anak Sekolah Dasar Kelas 1. Jurnal Ilmiah Mahasiswa Universitas Surabaya, vol. 4(1). 
Celo Belia Putri Birastuti, Fatah Yasin Al Irsyadi, Pembuatan Game Edukasi Tuntunan Sholat Fardhu Untuk Anak Berbasis Android

[4] Lucas, F. M. M. (2017). The Game As An Early Childhood Learning Resource For Intercultural Education. Procedia Sosial and Behavior Sciences, vol.237, 908-913.

[5] Sung, Y. T., Chang, K. E.,\& Liu, T. C. (2016). The Effect Of Integrating Mobile Devices With Teaching and Learning On Students' Learning
Performance: A Meta-analysis and Research Synthesis. Computer \& Education, vol. 94, 252-275.

[6] Supriyono, H., Saputra, A. N., Sudarmilah, E., \&Darsono, R. (2014). Rancang Bangun Aplikasi Pembelajaran Hadis Untuk Perangkat Mobile Berbasis Android.Jurnal Informatika, vol. 8(2). 